\title{
NOVEL TARIAN BUMI KARYA OKA RUSMINI (KAJIAN SEMIOTIKA CHARLES SANDERS PEIRCE)
}

\author{
Nurmaya Sari ${ }^{1}$, Anshari $^{2}$, dan Usman ${ }^{3}$ \\ Program Pascasarjana Magister Pendidikan Bahasa, Universitas Negeri Makassar, \\ Makassar, Sulawesi Selatan Indonesia \\ nurmayasari220@gmail.com
}

\begin{abstract}
ABSTRAK: Penelitian ini adalah jenis penelitian kualitatif. Data yang diperoleh disajikan dalam bentuk deskripsi yang dianalisis dengan cara pandang teori Semiotika Charles Sanders Peirce. Desain yang digunakan dalam penelitian ini adalah deskriptif kualitatif. Data-data yang dimaksud tersebut berupa kata, frasa, atau klausa yang mengandung ikon, indeks, dan simbol dalam novel Tarian Bumi karya Oka Rusmini. Fokus dalam penelitian ini adalah analisis novel Tarian Bumi karya Oka Rusmini dengan menggunakan kajian semiotika melalui deskripsi makna ikon, indeks, dan simbol. Teknik pengumpulan data dalam penelitian ini adalah teknik dokumentasi, teknik baca, dan teknik catat. Analisis data yang akan dilakukan pada penelitian ini mengikuti tiga tahap, yaitu: reduksi data, penyajian data, penyimpulan dan verifikasi data. Hasil pada penelitian ini ditemukan bentuk ikon, indeks, dan simbol pada novel Tarian Bumi karya Oka Rusmini dengan menggunakan kajian semiotika Charles Sanders Pierce. Pertama, bentuk ikon ditemukan tokoh Luh Sekar sebagai ikon perempuan ambisius, tokoh Telaga sebagai ikon perempuan keras, dan tokoh Sagra sebagai ikon perempuan yang tegas. Kedua, bentuk indeks ditemukan indeks penderitaan tokoh Luh Sekar dan indeks malangnya nasib tokoh Telaga. Ketiga, Simbol yang ditemukan dari penelitian ini adalah simbol budaya Bali.
\end{abstract}

Kata Kunci: Ikon, Indeks, Semiotika, dan Simbol,

\section{EARTH DANCE NOVEL BY OKA RUSMINI (SEMIOTIC STUDIES OF CHARLES SANDERS PEIRCE)}

\begin{abstract}
This type of research is qualitative research. The data obtained was presented in the form of a description analyzed by the semiotics theory of Charles Sanders Peirce. The design used in this study is descriptive qualitative. The data in question are words, phrases, or clauses containing icons, indexes, and symbols in the novel Dance of the Earth by Oka Rusmini. The focus of this study is the analysis of the novel Dance of the Earth by Oka Rusmini using semiotic studies through descriptions of the meaning of icons, indexes, and symbols. The data collection techniques used in this study are documentation techniques, reading techniques, and record techniques. The data analysis that will be conducted in this study follows three stages, namely: data reduction, data presentation, data collection and verification. The results in this study found the shape of icons, indexes, and symbols in the novel Earth Dance by Oka Rusmini using the semiotic study of Charles Sanders Pierce. First, the iconic shape was found by Luh Sekar as an ambitious female icon, Telaga figure as a hard female icon, and Sagra figure as a stern female icon. Second, the form of index found the suffering index of Luh Sekar figures and the unfortunate index of the fate of Telaga figures. Third, the symbol found in this study is a symbol of Balinese culture.
\end{abstract}

Keywords: Icons, Indexes, Semiotics, and Symbols.

\begin{tabular}{llll}
\hline Diterima: & Direvisi: & Distujui: & Dipublikasi: \\
2021-07-05 & 2021-07-08 & 2021-09-18 & 2021-10-29
\end{tabular}

Pustaka : Sari, Nurmaya, Anshari Anshari, \& Usman Usman. "NOVEL TARIAN BUMI KARYA OKA RUSMINI (KAJIAN SEMIOTIKA CHARLES SANDERS PEIRCE)." Fon: Jurnal Pendidikan Bahasa dan Sastra Indonesia [Online], 17.2 (2021): 135-145. Web. 29 Oct. 2021

\section{PENDAHULUAN}

Pengarang dapat menciptakan suatu karya sastra karena adanya pengalaman berupa peristiwa maupun kejadian menarik sehingga muncul ide, kemudian dipaparkan dalam bentuk tulisan. Lahirnya karya sastra di pengaruhi oleh adanya dorongan manusia untuk mengungkapkan eksistensi dirinya. Oleh sebab itu, pada umumnya karya sastra berisi tentang 
Program Studi Pendidikan Bahasa dan Sastra Indonesia FKIP Universitas Kuningan

permasalahan yang tercermin dalam kehidupan manusia, meskipun karya sastra hanya berupa fiksi, tetapi pada kenyataannya sastra juga bermanfaat memberikan nilai-nilai moral bagi pembacanya. Karya sastra juga dapat menjadi salah-satu sarana hiburan untuk memperoleh pengetahuan. Pembaca akan memperoleh kepuasan terendiri dengan membaca karya sastra. Ada berbagai macam karya sastra satu-satunya adalah novel.

Novel memiliki unsur keindahan sehingga orang yang membacanya dapat merasa senang, sedih, menarik perhatian, dan menyegarkan penikmatnya. Hal ini sependapat dengan Horace dalam (Wellek \& Warren, 2013) yang berpendapat bahwa esensi seni harus dihubungkan pada dua istilah yaitu utile dan dulce yang bermakna bermanfaat dan indah. Kedua istilah tersebut berkaitan dalam memahami arti sastra secara keseluruhan.

Salah seorang perempuan yang turut meramaikan dunia kesusastraan Indonesia adalah Oka Rusmini. Sastrawan yang tidak hanya dikenal di Bali, melainkan di Indonesia. Ciri khas dari tulisan Oka Rusmini yang mencerminkan budaya tradisional masyarakat Bali dengan tema perempuan membuatnya semakin menarik. Karya Oka Rusmini tersebut berjudul Tarian Bumi.

Novel Tarian Bumi dipilih sebagai objek kajian karena memiliki beberapa kelebihan, yaitu: (1) memiliki tema sentral tentang budaya Bali tradisional. Novel ini memberikan gambaran masyarakat Bali yang mengalami berbagai macam masalah sosial dan harus mematuhi berbagai aturan adat; (2) novel ini menguraikan sisi gelap perjalanan hidup perempuan Bali yang jarang ditemukan pada karya sastra yang sudah ada; (3) tokoh utama dalam novel tersebut adalah tokoh perempuan; dan (4) proses kreatif Oka Rusmini. Novel tersebut mendapat apresiasi oleh pembaca sastra khususnya di Indonesia, salah satunya novel Tarian Bumi, pada tahun 2003 sebagai Penerima Penghargaan Penulisan Karya Sastra oleh Pusat Bahasa Departemen Pendidikan Nasional Indonesia. (Mandrastuty, 2010).

Novel Tarian Bumi karya Oka Rusmini menceritakan kisah tokoh utama yang bernama Luh Sekar. Tokoh Luh Sekar adalah sosok perempuan yang penuh ambisi, segala harapan dan keinginan harus dapat ia capai bagaimanapun caranya. Keinginan pertama Luh Sekar ingin menjadi penari Joged yang terkenal dan menjadi wanita yang paling cantik dan seksi di antara penari yang ada. Berbagai usaha yang dilakukan akhirnya berbuah manis. Dia menjadi seorang penari paling cantik dan seksi. Keinginan selanjutnya ia ingin dipersinting dengan lelaki yang manyandang gelar bangsawan seorang dari keturunan kasta Brahmana, dan akhirnya ia pun mendapat seorang lelaki bangsawan yang bernama Ida Bagus Ngurah Pidada. Hasil dari buah cinta mereka mendapatkan seorang putri yang bernama Dayu Telaga Pidada. Telaga adalah sosok perempuan cantik yang berasal dari kasta Brahmana tetapi dia jatuh cinta dengan Wayan Sasmita seorang lelaki yang berasal dari kasta Sudra. Akhirnya gelar kebangsawanan yang dimiliki Telaga harus ditinggalkan karena dia menikah dengan lelaki yang beda kasta.

Penelitian ini sangat penting untuk dilakukan melihat perkembangan zaman yang semakin pesat, novel terus ditulis dan dibaca. Meskipun novel itu menarik karena ditulis dengan gaya bahasa dan imajinasi pengarang, namun masih banyak penikmat karya sastra, khususnya novel yang cenderung masih sulit menafsirkan makna yang hendak disampaikan oleh pengarang. Struktur novel yang sulit atau menggunakan bahasa yang tidak lazim dan kompleks mengakibatkan pembaca perlu membaca berulang kali sehingga makna yang hendak disampaikan dapat dipahami. Kadang kala, setiap pembaca memiliki 
Program Studi Pendidikan Bahasa dan Sastra Indonesia FKIP Universitas Kuningan

penafsiran yang berbeda-beda terhadap maksud yang ingin disampaikan melalui novel. Bisa jadi, tanda yang satu akan beda pemaknaannya apabila ditafsirkan oleh pembaca yang lain. Jadi, agar dapat memaknai pesan yang hendak disampaikan oleh pengarang diperlukan analisis dengan menguraikan tanda-tanda yang ada dalam novel.

Hal inilah yang membuat penulis sehingga memilih judul penelitian yang berkaitan dengan pemaknaan dalam novel. Apalagi di zaman yang dikategorikan sebagai zaman milenial, hanya orangorang tertentu yang mampu dan tertarik membaca karya sastra, padahal setiap karya sastra murni terdapat banyak sejarah dan pembelajaran yang bisa diaplikasikan di kehidupan sekarang. Saat ini mudamudi hanya sibuk menatap layar smartphone yang dipenuhi dengan aplikasi-aplikasi trendi tidak lagi menenteng novel, buku sejarah, dll tetapi lebih sibuk membaca status di berbagai sosial media. Zaman boleh milenial, tetapi pola pikir tidak boleh lupa akan ajaran agama, budaya dan adat istiadat.

Adapun cara dalam menganalisis novel novel untuk menemukan tanda-tanda dalam suatu karya sastra adalah dengan menggunakan kajian semiotika. Semiotika adalah cabang ilmu yang mengkaji tentang tanda, yang berusaha membeda tanda sehingga dapat diketahui maknanya (Hafiar dkk., 2017). Menurut Nurgiyantoro (2013) sesuatu yang dapat mewakili sesuatu yang lain baik berupa pengalaman, pikiran, perasaan, gagasan dapat disebut sebagai tanda. Jadi, bukan hanya bahasa saja yang dapat dikategorikan sebagai tanda, tetapi berbagai hal yang melingkupi kehidupan ini termasuk sebagai tandasekalipun harus diakui bahwa bahasalah tatanan tanda yang paling lengkap dan sempurna. Tanda-tanda tersebut dapat berupa gerak anggota tubuh, tulisan, warna, bendera, potongan rumah, pakaian, karya seni: sastra, lukis, patung, film, tari, musik, dan lain-lain yang terdapat di sekitar kehidupan kita, sehingga diperlukan penginterpretasian dalam pemaknaan. Adapun tokoh penting dalam mengemukakan teori tentang tanda adalah Charles Sanders Peirce

Penulis menggunakan kajian semiotika Charles Sanders Peirce bukan pendekatan semiotika yang lain karena, melalui pandangan atau teori Peirce menurut hemat penulis mempunyai keterkaitan yang relevansi. Dikatakan relevansi karena teori Charles Sanders Peirce selain lebih lugas, juga lebih jelas pengklasifikasiannya antara ikon, indeks, dan simbol sehingga, dapat mempermudah penulis dalam memahami dan memaknai.

Novel Tarian Bumi secara asumsi cocok dengan pendekatan semiotika yang meliputi ikon, indeks, dan simbol. Novel Oka Rusmini membawa latar sosiologis budaya Bali, dikatakan cocok karena ruang lingkup semiotika mencakup kejadian sosial yang ada dalam masyarakat dan kebudayaan itu termasuk tanda-tanda, semiotika juga membahas sistem, aturan, dan konvensi sehingga memungkinkan tanda-tanda tersebut memiliki arti (Jabrohim, 2014). Dengan demikan dapat disimpulkan bahwa pendekatan semiotika terhadap novel Oka Rusmini sudah tepat dalam pemilihan pendekatan atau pisau bedah.

Adanya kajian semiotika pada novel ini diharapkan kepada pembaca dapat memahami tanda-tanda yang dipakai pengarang. Sistem tanda atau lambang yang dituangkan pengarang dalam novel sebagai suatu hasil karya sastra Indonesia perlu diketahui dan dipahami karena setiap pengarang memiliki ciri khas tersendiri dalam menuangkan ide dan gagasannya dalam karya-karyanya.

Berdasarkan hal tersebut, peneliti tertarik melakukan penelitian dengan judul "Novel Tarian Bumi karya Oka Rusmini dengan menggunakan kajian semiotika 
Program Studi Pendidikan Bahasa dan Sastra Indonesia FKIP Universitas Kuningan

Charles Sanders Peirce" khususnya menemukan ikon, indeks, dan simbol.

\section{LANDASAN TEORI}

\section{A. Hakikat Sastra}

Sastra berasal dari bahasa Sansekerta, sas dalam kata kerja turunan mengandung arti arahkan, ajaran, memberi petunjuk, dan arahan, sedangkan kata tra dapat berfungsi sebagai sarana atau media. Sastra dapat diartikan sebagai sarana dalam mengarahkan, mengajarakan memberi petunjuk atau instruksi. Kemudian (Wellek, 2013) mengatakan bahwa segala sesuatu berupa bentuk tulisan atau yang tercetak itu merupakan sastra.

Suatu kegiatan yang tidak bisa lepas dari kehidupan manusia adalah kegiatan yang berkaitan dengan kebahasaan dan kekreatifan. Kedua hal itu sangat erat kaitannya dengan sastra. Kegiatan yang ada hubungannya dengan kekreatifan, misalnya sastra dipandang oleh Wellek \& Warren sebagai sesuatu kegiatan kreatif, sebuah karya seni. Menurut Teeuw (2003) sastra meliputi semua hal yang tertulis, menggunakan bahasa pada bahasa tulis, meskipun tidak semua bahasa tulis merupakan sastra. Ekspresi pengalaman tersebut mampu membuat manusia merasa tenteram dan menggembirakan, karena manusia mengetahui potensi yang ada dalam dirinya sehingga dapat menjalin hubungan yang akrab atas sesuatu yang menurutnya menarik dan membuatnya selalu dekat dengan sang pencipta.

Sastra adalah sebuah hasil budaya, yang diciptakan oleh pengarang berdasarkan pengalaman kehidupan dalam masyarakat. Posisi sastra berada antara kebebasan pengarang berkreasi dengan keadaan sosial yang di dalamnya terdapat aturan, kebiasaan, kepentingan ideologis, dan agama. Di tengah kehidupan masyarakat, sastra menjadi produk individu namun ia juga dapat dipandang menjadi proses dari kehidupan masyarakat.
Oleh sebab itu, sastra yang mengusung kebebasan karyanya dan berubah menjadi bentuk karya sastra, seketika itu pula ia harus berhadapan dengan berbagai aturan, moral, etika, dan kesepakatan masyarakat tersebut. (Noor, 2011).

Karya sastra tidak hanya mendahulukan isi, juga tidak hanya mementingkan wujud (bahasa), melainkan selalu berusaha memadukan kedua unsur tersebut secara harmonis ke dalam suatu bentuk karya sastra yang utuh. Tang (2008) menyatakan bahwa sastra adalah suatu institusi dalam kehidupan sosial dalam memanfaatkan bahasa sebagai mediumnya. Sastra dikemas melalui berbagai pengalaman dan pandangan terhadap hidup, namun kehidupan yang digambarkan tidak begitu konkret dan menyeluruh.

Muzakka (2017) berpendapat bahwa ideologi yang diikuti dan diyakini pengarang secara otomatis sangat mempengaruhi gagasan yang dituangkan menjadi bentuk karya. Gagasan yang disuguhkan penuls dalam karya sastranya lebih merupakan reaksi dan hasil pengamatan pengarang terhadap persoalan yang melingkupinya. Sastra juga dapat menjadi kebudayaan atau ciri khas seseorang dengan merujuk pada suatu daerah tertentu. Sastra dapat menjadi salasatu bentuk kebudayaan manusia yang dapat membudayakan manusia itu sendiri (Agustina, 2017).

Jadi sebagai kesimpulan bahwa sastra muncul dari hasil imajinasi pengarang melalui pengamatan dan pengalaman tentang berbagai peristiwa sosial yang biasanya terjadi pada kehidupan sosial yang dituang ke dalam model tulisan.

\section{B. Prosa Fiksi}

Secara etimologis, fiksi adalah hasil dari sesuatu yang dibentuk, dibuat, diciptakan dan sesuatu yang diimajinasikan. Sesuatu itu adalah ceritakisah yang dilukiskan oleh 
Program Studi Pendidikan Bahasa dan Sastra Indonesia FKIP Universitas Kuningan

pengarang. Prosa fiksi juga hampir sama denga karangan narasi sugestif atau imajinatif. Prosa fiksi merupakan peristiwa yang di mainkan oleh pelaku tertentu dengan penciptaan latar, tokoh, rangkaian cerita yang bertolak dari imajinasi pengarang sehingga terbentuk suatu cerita. (Aminuddin, 2011).

Fiksi berarti cerita yang muncul berdasarkan khayalan atau imajinasi karena fiksi merupakan karya naratif sehingga cerita yang tercipta mengarah dengan kenyataan seperti yang dikatakan oleh Abrams (Nurgiyantoro, 2013). Jadi, dalam sebuah cerita tidak diceritakan keadaan yang sebenarnya melainkan hanya imajinasi pengarang, sehingga tidak perlu mencari kebenaran dalam dunia nyata. Hal tersebut yang menyebabkan sehingga kesastraan prosa juga disebut sebagai fiksi.

Kenyataan dalam karya fiksi berupa ilusi kenyataan yang disuguhkan kepada penikmat sastra tidak selamanya berupa kenyataan sehari-hari. Menurut Nurgiyantoro (2013) prosa dapat juga disebut fiksi dalam ranah kesastraan, teks naratif yang berarti cerita rekaan atau khayalan karena isinya tidak menyangkut pada kebenaran faktual. Dengan kata lain, fiksi menunjuk pada karya sastra yang menceritakaan tentang suatu rekaan atau khayalan sehingga tidak perlu mencari kebenarannya. Prosa fiksi ini terbagi atas tiga yaitu: 1) novel; 2) roman; dan 3) cerpen. Adapun unsur-unsur prosa fiksi sebagai salah-satu genre sastra, meliputi; (1) pengarang atau narator, (2) isi penciptaan, (3) bahasa sebagai media penyampaian pesan, dan (4) elemenelemen fiksional yang berfungsi dalam pembentukan prosa fiksi sehingga menjadi wacana. Melihat dari sisi yang lain mengenai pemaparan isi, pengarang dapat menyuguhkan melalui penjelasan, monolog maupun dialog, serta lewat lakon atau action.

\section{Novel}

Asal kata novel dari bahasa latin yaitu novellas berubah menjadi novies, memiliki arti yaitu baru. Istilah baru ini merupakan fakta bahwa memang novel muncul belakangan dibandingkan dengan cerpen dan roman. (Mandrastuty, 2010).

Pengertian novel dalam The American College Dictionary yang dikutip oleh Henry Guntur Tarigan dalam (Mandrastuty, 2010) menjelaskan bahwa novel merupakan kisah rekaan yang dibentuk oleh beberapa tokoh, gestur, serta gaya kisah nyata yang representatif dalam sebuah kisah yang menimbulkan konflik. Hal tersebut sependapat dengan Burhan dalam (Mandrastuty, 2010) yang berpendapat bahwa novel adalah sebuah prosa fiksi yang bercerita secara lengkap. Novel menjadi sebuah karya sastra sastra, selain itu ada pula cerita pendek, puisi, dan drama. Fiksi merupakan cerita khayalan dan termasuk sebagai cerita naratif yang di dalamnya bukan berdasarkan kebenaran sejarah, atau tidak sungguh-sungguh terjadi dalam kehidupan nyata. Kejadian yang terdapat dalam cerita fiksi adalah kejadian yang bersifat imajinatif (AlMa'ruf \& Nugrahani, 2017).

lewat novel, penulis dapat menuangkan berbagai konflik, apakah permasalahan manusia dengan kehidupan, atau hidup dengan kehidupan, kemudian melakukan pengamatan terhadap permasalahan tersebut dengan sungguhsungguh sehingga dapat diungkapkan kembali dalam bentuk tulisan dengan menggunakan sarana fiksi yang imajinatif, tetapi biasanya cerita yang disuguhkan mengandung kebenaran bahkan membuat pembaca ikut terbawa dalam kisah itu.

Menurut Wallek dan Warren dalam (Al-Ma'ruf \& Nugrahani, 2017) novel adalah kisah yang menggambarkan kehidupan dan perilaku manusia dari zaman ke zaman. seperti dengan pendapat di atas, Damono dalam (Al-Ma'ruf \& Nugrahani, 2017) berpendapat bahwa novel adalah jenis sastra yang bersifat 
Program Studi Pendidikan Bahasa dan Sastra Indonesia FKIP Universitas Kuningan

rekaan, tetapi jalan ceritanya berdasarkan peristiwa kehidupan nyata dan berperan mendidik pengalaman batin pembaca.

Berdasarkan beberapa pandangan di atas, disimpulkan bahwa novel yaitu cerita fiktif yang muncul dari hasil pengalaman dan pengamatan pengarang tentang permasalahan kehidupan yang di susun dalam suatu kisah. Novel menjadi jenis cerita fiksi yang terakhir muncul dibandingkan dengan cerita fiksi yang lain. Novel menyuguhkan beberapa konflik yang terjadi oleh para tokoh. Kemudian tokoh-tokoh, berbagai kejadian, dan latar disajikan secara runtut dan kompleks sehingga ceritanya lebih panjang dibanding dengan karya sastra yang lain.

\section{Semiotika Charles Sanders Peirce}

Peirce mengemukakan bentuk triadik sebagai "triangle meaning semiotics" atau teori segitiga makna. Konsep trikotomi model triadik Peirce terdiri atas: (1) Representament/sign (tanda), (2) object (sesuatu yang dirujuk), (3) interpretant (hasil hubungan representamen dengan objek) (Utaridah, t.t.). Sedangkan menurut Zoest (1993) Peirce membedakan tanda menjadi tiga bagian, yakni ground, objek, dan interpretant: (1) berdasarkan groundnya, Peirce membaginya dalam tiga bentukyaitu: qualisign, sinsign, dan legisign, (2) berdasarkan interpretant, terdiri atas: rheme, decisign, dan argument; dan (3) berdasarkan objeknya, terdiri atas: ikon, indeks, dan simbol.

Peirce memfokuskan tanda berdasarkan denotatumnya terbagi menjadi tiga aspek yaitu, ikon, indeks, dan simbol. Model tanda berdasarkan pandangan Peirce yaitu trikotomis atau triadik, tidak ada ciri-ciri struktural sama sekali. Hanya berdasar bahwa tanda yang sifatnya representatif, artinya sesuatu yang yang menjadi perwakilan dari sesuatu yang lain (Gusmail, 2018). Penelitian ini berfokus pada trikotomi kedua, yaitu hubungan objek dengan tanda. Ikon dan indeks sebagai pembentukan tanda yang sangat sederhana dan sombol merupakan pembentukan tanda yang sangat modern (Ariffin \& Rijal, 2019).

\section{Ikon}

Ikon adalah tanda yang menunjukkan antara tanda dengan objeknya bisa menjandi hubungan kemiripan. Sebuah peta dan sebuah potret termasuk ikon (Sudjiman \& Zoest, 1992). Ikon merupakan kaitan tanda dengan petandanya bersifat sama yang dibentuk secara alamiah atau dapat dikatakan bahwa ikon merupakan hubungan kemiripan antara tanda dengan acuannya, potret dan peta termasuk ikon (Sobur, 2016). Ikon dapat berupa hubungan kemiripan, tanda ikon misalnya penyebutan, atau penempatan di bagian awal atau depan (sebagai tanda yang dianggap sesuatu yang penting) (Nurgiyantoro, 2013). Tanda yang mempunyai kaitan yang hubungan erat atau kesamaan dengan arti yang ditunjuk disebut ikon. Misalnya, orang yang difoto dengan foto atau wilayah geografis dengan petanya (Endraswara, 2013). Ikon merupakan kaitan tanda dan acuannya karena serupa, seperti foto (Ratna, 2014). Bagi Peirce, ikon merupakan tanda berdasarkan "keserupaan" atau "kemiripan" (resemblance) di antara representamen dan objeknya, baik objek tersebut betul-betul eksis atau tidak. Kaitan itu merupakan kaitan persamaan (Jabrohim, 2014).

\section{Indeks}

Hubungan yang muncul disebabkan ada kedekatan eksistensi. Sebuah penunjuk angin dan tiang penunjuk jalan merupakan indeks (Sudjiman \& Zoest, 1992). Indeks adalah tanda (representamen) yang menunjuk kepada konsep (interpretan) mengenai objek tertentu atas dasar kaitan kausalitas atau kontiguitas (Faruk, 2012).

Sebuah tanda yang langsung merujuk pada kebenaran atau tanda yang menggambarkan hubungan secara alami antara tanda dan penanda yang mengandung hubungan sebab akibat 
Program Studi Pendidikan Bahasa dan Sastra Indonesia FKIP Universitas Kuningan

disebut indeks. Contohnya asap dapat dijadikan sebagai tanda bahwa ada api (Sobur, 2016). Indeks merupakan hubungan kedekatan eksistensi, misalnya wajah yang muram menandakan hati yang sedang sedih, ditegur tetapi tidak mamerespon menandakan sifat sombong, asap hitam tebal membumbung menandakan adanya kebakaran, (Nurgiyantoro, 2013). Tanda yang mengandung hubungan sebab-akibat dengan apa yang ditandakan disebut indeks. Misalnya, mendung menandakan bahwa akan turun hujan (Endraswara, 2013). Indeks merupakan hubungan sebab akibat (Ratna, 2014).

\section{Simbol}

Simbol merupakan kaitan yang telah terbentuk secara konvensional. Mengangguk dapat menandakan persetujuan dan tanda-tanda kebahasaan juga merupakan simbol (Sudjiman \& Zoest, 1992). Simbol (lambang) merupakan tanda yang kaitan tanda dan objeknya ditentukan oleh suatu peraturan yang disepakati secara konvensional. Misalnya, seseorang menganggukkan kepala ketika ditanya jika dikaitkan kepada sebuah konvensi yang berarti "menjawab dengan membenarkan", maka dalam terminologi Peirce, simbol merupakan suatu third (Zoest, 1993).

Konsep Peirce, bahwa tanda yang merujuk pada objek tertentu di luar konteks disebut sebagai simbol. Kaitannya antara simbol kepada sesuatu yang ditandakan bersifat konvensional. Masyarakat penggunanya mengartikan ciri kaitan simbol kepada objek yang dituju dan mengartikan makna Berdasarkan kesepakatan tersebut. (Sobur, 2016). Apabila hubungan sudah terbentuk secara konvensi berarti tanda tersebut termasuk simbol. Tanda yang mencakup beberapa hal yang telah mengonvensi di masyarakat. Hubungan antara tanda dengan objek tidak memperlihatkan hubungan kemiripan ataupun kedekatan, tetapi terbentuk karena adanya kesepakatan. Misalnya, gerakan anggota tubuh sebagai tanda untuk menyampaikan maksud-maksud tertentu, warna tertentu (misalnya merah, putih, hitam, dan kuning) menandai (melambangkan) sesuatu tertentu pula, dan bahasa. (Nurgiyantoro, 2013).

\section{METODE}

Penelitian ini merupakan jenis penelitian kualitatif. Penelitian yang sifatnya mendeskripsikan secara alamiah fenomena yang menjadi sasaran penelitian. Alamiah dalam hal ini fenomena yang menjadi sasaran pada penelitian dideskripsikan sebagaimana adanya tanpa disertai perlakuan, pengukuran, dan perhitungan. Data yang temukan disajikan dalam bentuk deskripsi yang dianalisis berdasarkan cara pandang teori Semiotika C.S. Peirce.

Desain yang digunakan yaitu deskriptif kualitatif berdasarkan teknik analisis konten sebagaimana data yang didapatkan kemudian dianalisis berdasarkan penjelasan secara deskriptif. Data-data yang dimaksud dapat berupa kata, frasa, atau klausa yang mengandung ikon, indeks, dan simbol dalam novel Tarian Bumi karya Oka Rusmini. Fokus dalam penelitian ini adalah analisis novel Tarian Bumi karya Oka Rusmini berdasarkan kajian semiotika melalui deskripsi makna ikon, indeks, dan simbol. Data dapat berupa berupa kata, frasa, klausa, atau kalimat penggalan dalam novel Tarian Bumi karya Oka Rusmini yang berbentuk narasi, dialog, dan monolog yang memuat ikon, indeks, dan simbol.

Sumber data dalam penelitian ini diperoleh dari novel karya Oka Rusmini yaitu novel Tarian Bumi yang diterbitkan pada tahun 2000 oleh badan Penerbit Gm Pustaka Utama dengan jumlah 176 halaman. Pada penelitian ini teknik yang digunakan dalam pengumpulan data adalah teknik dokumentasi, teknik baca, dan 
Program Studi Pendidikan Bahasa dan Sastra Indonesia FKIP Universitas Kuningan

teknik catat. Penelitian ini adalah penelitian kualitatif semua data yang diperoleh akan dideskripsi berdasarkan ciri-ciri asli data selama proses pengumpulan data sampai selesai. Menurut Miles (2009) penelitian ini mengikuti tiga tahap analisis data yang akan dilakukan yaitu: mereduksi data, menyajikan data, menyimpulkan dan verifikasi data.

\section{HASIL DAN PEMBAHASAN}

Hasil analisis data disajikan berdasarkan atas pemahaman peneliti dengan teori Semiotika Charles Sanders Pierce. Penulis memaparkan hasil penelitian dengan mempertimbangkan deskripsi bentuk ikon, indeks, dan simbol dalam novel Tarian Bumi karya Oka Rusmini dengan menggunakan kajian semiotika C.S. Pierce.

\section{A. Ikon dalam novel Tarian Bumi karya Oka Rusmini Kajian Semiotika C. S Peirce}

Ikon yang ditunjukkan penulis dalam novelnya dipaparkan sebagai berikut. Tokoh Luh Sekar sebagai ikon perempuan ambisius karena begitu banyak keinginannya yang harus terwujud apapun sanksinya. Luh Sekar adalah perempuan sudra yang memiliki impian yang terlalu tinggi. Pertama yang menjadi keinginan Luh Sekar yang harus segera diwujudkan adalah menjadi seorang istri laki-laki Brahmana karena dipikirannya menjadi seorang istri bangsawan itu akan mengangkat derajatnya dan derajat keluarganya. Keinginan selanjutnya adalah dia harus menjadi penari, Luh Sekar percaya bahwa dirinya adalah perempuan yang memiliki kecantikan yang khas juga berbakat, dia ingin membuktikan kepada semua orang bahwa dia mampu menjadi satu-satunya penari yang memiliki ratusan kekuatan dewa tari, gerakan yang khas dapat menghidupkan sekehe joged desanya. Bahkan setelah Luh Sekar memiliki seorang anak, dia sangat berharap anaknya kelak menikah dengan laki-laki yang bangsawan yang sederajat dengannya, dia juga ingin agar anaknya menjadi seorang penari yang sangat cantik.

Tokoh Telaga sebagai ikon perempuan keras tergambar jelas dalam novel ketika prempuan itu tumbuh dewasa dia sangat membenci proses yang terjadi pada dirinya dan kehidupannya karena begitu banyak aturan-aturan yang harus dipatuhi sebagai wanita yang berasal dari kasta Brahmana atau keturunan bangsawan. Tidak ada yang mampu menentang suatu hal yang sudah menjadi keinginannya. Apalagi setelah perempuan itu mengenal seorang laki-laki sudra yang tumbuh dalam hatinya Ambisiambisi yang telah yang dititipkan Ibu padanya.

Tokoh Sagra sebagai ikon perempuan yang tegas karena perempuan tua itu berasal dari keturunan bangsawan kaya, perempuan tua itu sangat menjunjung tinggi harga diri nilai-nilai kebangsawanan. Dia memiliki seorang putra semata wayang, dia berharap kelak putranya itu menyunting wanita yang memiliki nama depan Ida Ayu bukan Ni Luh. Namun, itu tidak seperti dengan harapan yang dititipkan oleh anaknya, anaknya malah menyunting wanita sudra yang nama depannya Ni Luh, sejak saat itu dia begitu keras kepada sekar karena dia tidak pernah merestui hubungannya dengan anak semata wayangnya itu. Sekar selalu menjadi korban ketika ada masalah yang terjadi, mertuanya itu selalu memakinya dengan kata-kata yang kasar.

\section{B. Indeks dalam novel Tarian Bumi karya Oka Rusmini Kajian Semiotika C. S Peirce}

Indeks dalam novel Tarian Bumi karya Oka Rusmini terdapat dua bentuk yakni indeks penderitaan tokoh Sekar dan indeks malangnya nasib tokoh Telaga. Indeks penderitaan tokoh Sekar disebabkan setelah dia menikah dengan laki-laki yang berasal kasta Brahmana keturunan Bangsawan. Sekar berpikir dengan itu akan mengangkat hidupnya dan 
Program Studi Pendidikan Bahasa dan Sastra Indonesia FKIP Universitas Kuningan

keluarganya, tapi ternyata tidak. Setelah resmi menjadi istri laki-laki Brahmana itu begitu banyak penderitaan yang dihadapi Sekar. Hal yang paling menyakitkan yang harus ditanggung oleh Sekar adalah dia tidak bisa lagi menggunakan nama Ni Luh Sekar, seorang perempuan yang menikah dengan lelaki yang berasal kasta Brahmana namanya akan berubah. Sekar harus membiasakan dirinya dengan sebutan Jero Kenanga. Luh Sekar juga harus meninggalkan keluarga dan kebiasaankebiasaannya. Bahasa ibu Sekar juga harus sopan kepada anaknya kerena dia tidak lagi sederajat. Luh Sekar juga harus terusmenerus menghadapi mertua perempuannya yang begitu keras dan selalu marah kepadanya.

Indeks malangnya nasib tokoh Telaga tergambar setelah Telaga menikah bersama lelaki yang tidak sekasta. Perempuan Bali terikat oleh aturan adat. berdasarkan adat budaya Bali perempuan yang berasal dari kasta Brahmana tidak diperbolehkan menikah dengan laki-laki yang beda kasta atau yang berasal dari kasta Sudra. Peristiwa tersebut yang menyebabkan malangnya kehidupan Telaga, karena Telaga tidak diterima sebagai menantu. Menurut kepercayaan masyarakat Bali seorang laki-laki Sudra dilarang menikahi perempuan Brahmana. Akan sial jadinya jika hal tersebut terjadi. Begitu pula kisah kehidupan Telaga yang telah resmi menikah dengan laki-laki Sudra begitu banyak kemalangan yang terjadi pada dirinya. Kehidupan Telaga sangat berubah, dia harus meninggalkan semua kebiasaannya sebagai wanita Brahmana, dan tak sebutir berlian pun yang bisa dia bawah karena dia menikah bersama lelaki Sudra. Tidak lama setelah menikah, suaminya meninggal. Hal itu membuat mertuanya semakin yakin bahwa Telaga mendatangkan kesialan. Dia juga harus berhadapan dengan adik ipar yang selalu meremehkannya.

\section{C.Simbol dalam novel Tarian Bumi karya Oka Rusmini Kajian Semiotika C. S Peirce}

Simbol dalam novel Tarian Bumi karya Oka Rusmini adalah simbol budaya Bali. Simbol budaya Bali yang begitu banyak digunakan oleh pengarang pada novel tersebut. Novel yang mengisahkan tentang kehidupan budaya bali sehingga banyak menyuguhkan istilah-istilah masyarakat Bali, misalnya dari segi penggunaan bahasa sehari-hari, tempat, kata ganti orang, maupun perlengkapan upacara adat. Simbol ini memiliki makna khusus sehingga dapat menjadi pedoman hidup bagi masyarakat Bali dan semuanya tergambar dalam kalimat-kalimat Bali yang digambarkan dalam novel ini. Simbol yang terdapat dalam novel ini terkait dengan budaya memuat berbagai macam aspek baik pada aspek penggunaan katakata bagi petunjuk hidup masyarakat Bali, begitupun kesenian yang sudah menjadi tradisi telah diwariskan hingga sekarang, beberapa identitas tempat dan kebiasaan yang juga sudah ada sejak dahulu adalah bagian dari simbol budaya masyarakat Bali yang masing-masing memiliki arti tersendiri.

\section{PENUTUP}

Hasil dalam penelitian ini ditemukan bentuk ikon, indeks, dan simbol dalam novel Tarian Bumi karya Oka Rusmini dengan menggunakan kajian semiotika C.S. Pierce.

1. Ikon yang ditemukan dalam novel Tarian Bumi karya Oka Rusmini yaitu tokoh Luh Sekar sebagai ikon perempuan ambisius karena begitu banyak keinginannya yang harus terwujud apapun sanksinya. Tokoh Telaga sebagai ikon perempuan keras tergambar jelas dalam novel ketika prempuan itu sudah dewasa dia sangat membenci proses yang terjadi pada tubuh dan kehidupannya karena begitu banyak aturan-aturan yang harus 
Program Studi Pendidikan Bahasa dan Sastra Indonesia FKIP Universitas Kuningan

dipatuhi sebagai wanita yang yang berdarah bangsawan. Tokoh Sagra sebagai ikon perempuan yang tegas karena perempuan tua itu merupakan putri bangsawan kaya, perempuan yang sangat mengagungkan nilai-nilai kebangsawanan.

2. Indeks yang ditemukan dalam novel Tarian Bumi karya Oka Rusmini yaitu indeks penderitaan tokoh Sekar dan indeks malangnya nasib tokoh Telaga. Indeks penderitaan tokoh Sekar disebabkan setelah dia menikah bersama lelaki yang berasal dari kasta Brahmana atau keturunan bangsawan. Indeks malangnya nasib tokoh Telaga tergambar setelah Telaga menikah bersama lelaki yang tidak sekasta yaitu laki-laki yang berasal dari kasta Sudra.

3. Simbol yang ditemukan dalam novel Tarian Bumi karya Oka Rusmini adalah simbol budaya Bali. Simbol budaya Bali yang begitu banyak digunakan oleh pengarang dalam novel ini. Novel yang mengisahkan tentang kehidupan budaya Bali sehingga banyak menyuguhkan istilah-istilah masyarakat Bali, misalnya dari segi penggunaan bahasa seharihari, tempat, kata ganti orang, maupun perlengkapan upacara. Simbol tersebut memiliki makna tersendiri sehingga dapat menjadi pedoman hidup bagi masyarakat Bali.

\section{DAFTAR PUSTAKA}

Agustina, L. (2017). Analisis Semiotik dalam Kumpulan Cerpen Air Mata Ibuku dalam Semangkuk Sup Ayam. STILISTIKA: Jurnal Bahasa, Sastra, dan Pengajarannya, 2(1). https://doi.org/10.33654/sti.v2i1.37 8

Al-Ma'ruf, A. I., \& Nugrahani, F. (2017). Pengkajian Sastra: Teori dan Aplikasi. CV. Djiwa Amarta Press. Aminuddin. (2011). Pengantar Apresiasi Sastra. Sinar baru.
Endraswara, S. (2013). Metodologi Penelitian Sastra: Epistemologi, Model, Teori, dan Aplikasi. CAPS.

Faruk. (2012). Metode Penelitian Sastra: Sebuah Penjelajahan Awal. Pustaka Belajar.

Gusmail, S. (2018). Properti Tari Waktu dalam Lipatan: Analisis Semiotika Melalui Pendekatan Charles Sanders Peirce. 14 (1), 12.

Hafiar, H., Mahameruaji, J. N., \& Rahmawan, D. (2017). Analisis Semiotika Pada Cover Novel Trilogi Karya Vira Safitri. Jurnal Nomosleca, 3(1). https://doi.org/10.26905/nomoslec a.v3i1.1177

Jabrohim. (2014). Teori Penelitian Sastra. Pustaka Belajar.

Mandrastuty, R. (2010). Skripsi Novel Tarian Bumi Karya Oka Rusmini: Kajian Feminisme. 75.

Muzakka, M. (2017). Novel Gadis Pantai Karya Pramoedya Ananta Toer: Analisis Hegemoni *) (A Novel Gadis Pantai by Pramoedya Ananta Toer: an Hegemony Analysis). Jurnal ALAYASASTRA, Vol. 13(1), 13.

https://doi.org/10.36567/aly.v13i1. 73

Noor, R. M. (2011). Pendidikan Karakter Berbasis Sastra, Solusi Pendidikan Moral yang Efektif. Yogyakarta: Ar Ruz Media.

Nurgiyantoro, B. (2013). Teori Pengkajian Fiksi. Gadjah Mada University Press.

Ratna, N. K. (2014). Stilistika: Kajian Puitika Bahasa, Sastra, dan Budaya. Pustaka Belajar.

Sehandi, Y. (2016). Mengenal 25 Teori Sastra. Ombak.

Sobur, A. (2016). Semiotika Komunikasi. PT Remaja Rosdakarya.

Tang, M. R. (2008). Mozaik Dasar Teori Sastra dalam Penampungan Objektif. Badan Penerbit UNM. 
Program Studi Pendidikan Bahasa dan Sastra Indonesia FKIP Universitas Kuningan

Teeuw, A. (2003). Sastra dan Ilmu Sastra, Pengantar Teori Sastra. Pustaka Jaya.

Wellek, R., \& Warren, A. (2013). Teori Kesusastraan (Terjemahan Melanie Budianto). Gramedia.

Zoest, A. V. (1993). Semiotika: Tentang Tanda, Cara Kerjanya, dan Apa yang Kita Lakukan Dengannya. Terj Ani Soekowati. Yayasan Sumber Agung.

https://sloap.org/journals/index.php/ijllc/ar ticle/view/225 